\title{
Grape marc extract acts as elicitor of plant defence responses
}

\author{
Pascale Goupil $^{1,2}$, Razik Benouaret ${ }^{1,2}$, Olivia Charrier ${ }^{1,2}$, Alexandra ter Halle ${ }^{3,4}$, Claire Richard ${ }^{3,4}$, Boris \\ Eyheraguibel $^{3,4}$, Denis Thiery ${ }^{5}$, Gérard Ledoigt ${ }^{1,2}$ \\ ${ }^{1}$ Clermont Université, Université Blaise Pascal, UMR 547 PIAF, 63000 Clermont-Ferrand, France \\ ${ }^{2}$ INRA, UMR 547 PIAF, 63100 Clermont-Ferrand, France \\ ${ }^{3}$ Clermont Université, Université Blaise Pascal, Institut de Chimie de Clermont-Ferrand, BP 10448, 63000 \\ Clermont-Ferrand, France \\ ${ }^{4}$ CNRS, UMR 6296, Institut de Chimie de Clermont-Ferrand, 63171 Aubière \\ ${ }^{5}$ UMR 1065 Santé et Agroécologie du Vignoble, Institut des Sciences de la Vigne et du Vin, INRA BP 81 \\ Villenave-d'Ornon Cedex 33883 France
}

Author for correspondence: Pascale Goupil

Phone: (33) 04734079 40- Fax: (33) 04734079 42- E-mail: Pascale.GOUPIL@univ-bpclermont.fr

Article accepted in Ecotoxicology 6 april 2012- available on line 1 may 2012

\begin{abstract}
Plant protection based on novel alternative strategies is a major concern in agriculture to sustain pest management. The marc extract of red grape cultivars reveals plant defence inducer properties. Treatment with grape marc extract efficiently induced hypersensitive reaction-like lesions with cell death evidenced by Evans Blue staining of tobacco leaves. Examination of the infiltration zone and the surrounding areas under UV light revealed the accumulation of autofluorescent compounds. Both leaf infiltration and a foliar spray of the red grape extract on tobacco leaves induced defence gene expression. The $P R 1$ and $P R 2$ target genes were upregulated locally and systemically in tobacco plants following grape marc extract treatment. The grape extract elicited an array of plant defence responses making this natural compound a potential phytosanitary product with a challenging issue and a rather attractive option for sustainable agriculture and environmentally friendly practices.
\end{abstract}

Keywords: Elicitor, Grape marc, Pathogenesis related protein genes, Plant defence reactions, Tobacco

\section{Introduction}

Over the last few decades, there has been increasing concern about environmental pollution and damage to biodiversity as a result of the intensive use of chemical phytosanitary products. Significant research efforts have been expended to identify and develop newer and safer compounds modelled on natural systems. Currently, fast emerging natural phytosanitary products are known as plant defence inducers (PDIs). These compounds are capable of triggering plant immune responses (Reglinski et al. 2007). The induction of the host plant defence system is a promising strategy to reduce pesticide use in conventional agricultural practices diminishing negative side effects on both the environment and human health (Walling 2001; Harm et al. 2011).

Pathogen-derived metabolites (elicitors) are recognised by putative plant cell receptors and activate a complex network of signal transduction pathways and a variety of biochemical and molecular defence mechanisms. The signalling pathways mediated by microbial elicitors involve secondary signals such as salicylic acid (SA), 
jasmonic acid (JA) and ethylene. These bioactive molecules can either act independently or in combination to orchestrate local and systemic induction of defence responses (Shah 2009; Yang et al. 2011). Systemic acquired resistance (SAR) refers to a SA-dependant pathway and plays an important role in the ability of plants to defend themselves against pathogens (Durrant and Dong 2004; Conrath 2006). After the formation of a necrotic lesion, either as part of the hypersensitive response (HR) or as a disease symptom, a local acquired response (LAR) is induced (Costet et al. 1999) and the SAR pathway is activated. LAR and SAR pathway activation results in the development of a broad-spectrum resistance associated with the modified expression of a large number of defence genes whose products may play crucial roles in restricting pathogen growth. Typical marker genes of SAR induction include the pathogenesis-related protein PR1 or other acidic PR proteins with antimicrobial activity (Edreva 2005; Van Loon et al. 2006). Tobacco is best studied model system for studying SAR induction. Analysis of SAR in tobacco has resulted in a number of significant findings that have shed light on plant defence-induced transduction pathways. In tobacco, SAR activation results in a significant reduction of the disease symptoms caused by oomycetes Peronospora tabacina and Phytophthora parasitica, fungi Cercospora nicotianae, virus (tobacco mosaic virus and tobacco necrosis virus), and bacteria Pseudomonas syringae and Erwinia carotovora (Vernooij et al. 1995).

PDI-containing biomolecules can be used as stimulus-triggering factors to mobilize plant defence reactions. These non-specific elicitors are structurally diverse compounds such as oligosaccharides, polysaccharides, peptides, proteins and lipids; most are derived from the plant or pathogen cell surface (Walters et al. 2005; Lyon 2007). PDIs activate SAR and induce protection against a variety of pathogens for a large spectrum of vegetables and crops (Reignault and Walters 2007). Identification of new PDIs could provide an exploitable perspective important for phytoimmunology, biotechnology and environment. There are several plant extracts that act as efficient PDIs. Extracts from Hedera (Baysal and Zeller 2004), Laminaria (Aziz et al. 2003), Reynoutria (Konstantinidou-Doltsinis et al. 2006), Trigonella (Martinez et al. 2006) and Rheum/Frangula (Godard et al. 2009) have been shown to induce plant defence reactions and promote disease suppression in susceptible host plants. Trigonella extracts and Laminaria extracts are currently approved in France as PDIs.

In the present report, we investigate plant defence reactions mediated by red grape marc extract at the molecular level in tobacco. The uniqueness of this product is due to its origin and nature. Grape marc extract (GME) is a wine by-product that contains a large proportion of polyphenols with anthocyanins. GME has recently been shown to act as a pesticide photoprotector (Eyheraguibel et al. 2010). Differential $P R$ gene expression and localised cell death following GME treatment suggest that GME may act as a PDI. This new class of 
phytosanitary bioproduct combining reduced input properties can make it an exceptionally well-suited product for environmentally oriented crop protection scheme.

\section{Materials and Methods}

Biological compounds and chemicals Grape marc extract (GME) is a Vitis vinifera L. hydroalcoholic extract provided as red powder by Grap'Sud (Cruviers-Lascours, France, lot \#08010). Pesticide ( $<1 \mathrm{ppm}$ ), heavy metal $(<3 \mathrm{ppm})$ and bacterial (E. coli-, Salmonella- and total coliforms- free) contents were certified by the company. The industrial process used to create the GME powder consists of an ethanol $(<30 \% \mathrm{v} / \mathrm{v})$ extraction of polyphenols followed by atomisation. The end product contains less than $100 \mathrm{ppm}$ of residual solvent. GME is produced from marc of grapes harvested from several red wine varieties (e.g., Merlot, Syrah, Carignan, Grenache, Cabernet and Alicante) cultivated in Southern France. GME powder was prepared as a $1 \%$ aqueous solution and serially diluted 4-fold (0.25\%), 8-fold $(0.125 \%), 16$-fold $(0.0625 \%), 32$-fold $(0.0312 \%)$ and 64 -fold $(0.0156 \%)$ prior to use for dose-dependent experiments. Salicylic acid (SA), jasmonic acid (JA) and $\beta$ aminobutanoic acid (BABA) were purchased from Sigma (St. Quentin Fallavier, France).

Plant material and treatments The biological activity of GME was assayed on 3-month old tobacco plants (Nicotiana tabacum L.) when plants had developed 20 to 22 fully expanding leaves (preflowering stage). Tobacco plants were grown in the greenhouse under controlled conditions $\left(22^{\circ} \mathrm{C} \pm 5^{\circ} \mathrm{C}\right.$ with a photoperiod of $16 \mathrm{~h}$ of light). GME was applied as an aqueous solution to foliar tissue either by infiltration or as an aerosol spray. Leaf infiltration was carried out on leaf blades using a plastic syringe. Routinely, $50 \mu 1$ was infiltrated until the solution was spread across a leaf area of 1 to $2 \mathrm{~cm}^{2}$. Foliar spray treatments were administered by spraying onto the adaxial (upper) face of three leaves with a fine atomizer ( $2 \mathrm{ml}$ per leaf). As a positive control, leaves were infiltrated or sprayed with $2 \mathrm{mM} \mathrm{SA}$. For the negative control, the leaves were infiltrated or sprayed with ultrapure water. The compounds (GME, SA and BABA) were infiltrated into distinct areas on the same leaf for the examination of macroscopic symptoms under bright field or UV light (at $312 \mathrm{~nm}$ ). Aerosol leaf sprays were monitored on the median leaves of a tobacco plant. The unsprayed leaves (USL) used to investigate the systemic defence reactions were those located immediately above and below the sprayed leaves (SL). 
Cell death assay Cell death in tobacco leaf tissue was monitored by Evans Blue staining (Baker and Mock 1994). Each assay was performed with 10 leaf disks $(1 \mathrm{~cm}$ in diameter) punched out from each infiltrated area of the same leaf (triplicate on the same leaf). Leaf disks were incubated for $30 \mathrm{~min}$ in $0.25 \%$ Evans Blue (Sigma, France) at room temperature on a rotary shaker, rinsed extensively to remove the excess dye and ground in a tissue grind tube with $1 \mathrm{ml} \mathrm{1 \%} \mathrm{SDS}$. The leaf extract was centrifuged for $20 \mathrm{~min}$ at $20000 \mathrm{xg}$ and the supernatant was diluted 8 -fold with water. The dye was quantified using spectrophotometry by monitoring the absorbance at $600 \mathrm{~nm}$.

RNA isolation and quantification Leaf tissues $(200 \mathrm{mg})$ were grounded in liquid nitrogen and RNA extraction was performed using $1 \mathrm{ml}$ Tri-reagent (Euromedex, France) according to manufacturer's instructions. Total RNA were cleaned up with 0.5U DNase I solution (Euromedex, France) solution containing 20U RNase inhibitor (Euromedex, France). RNA integrity was verified on a $1 \%$ agarose gel by detecting ribosomal RNAs. RNA concentrations were measured spectrophotometrically at $260 \mathrm{~nm}$. Reverse transcription was performed using $1 \mu \mathrm{g}$ of the total RNA and Euroscript Reverse Transcriptase (Eurogentec, France) according to manufacturer's instructions.

A quantitative assessment of mRNA levels was performed using an iCycler iQv3 (BIO-RAD). PCR reactions were prepared using the qPCR kit Mastermix for SYBR green (Eurogentec, France) according to the manufacturer's protocol. The cDNA concentration used produced a threshold cycle value $\left(\mathrm{C}_{\mathrm{T}}\right)$ between 15 and 30 cycles. PCR efficiencies were calculated for each gene according to Pfaffl (2001). The abundance of $P R$ transcripts was normalised to the transcript abundance of the reference gene (EF-1 $\alpha)$ (Peng et al., 2004) and set relative to control plants (ultrapure water infiltrated or sprayed) following the $2^{-\Delta \Delta \mathrm{CT}}$ method. The relative $P R$ transcript quantities are the mean of at least three technical replicates. Two treated plants were pooled for each experiment and the results are presented as the means of duplicate experiments. Bars represent the mean values \pm standard error (SE).

Primers were designated according to their availability in NCBI Genbank (http://www.ncbi.nlm.nih.gov/). Primer sequences are listed in Table 1. Both forward and reverse primers cover a relatively short sequence (approximately $150 \mathrm{bp}$ ) and were designed with a GC percentage of approximately $60 \%$. The specificity of amplicons was routinely verified by melt curve analysis at the end of each run and by $1.2 \%$ agarose gel electrophoresis after gene amplifications using 2.5U Taq DNA polymerase (Sigma, France) with the following thermal cycling program: $30 \mathrm{~s}$ at $95^{\circ} \mathrm{C}, 30 \mathrm{~s}$ at the Tm of the primers (Table 1) and $30 \mathrm{~s}$ at $72^{\circ} \mathrm{C}$. 
Table 1: Sequences of gene-specific primers used for real-time quantitative real-time RT-PCR

\begin{tabular}{|l|l|l|l|l|c|c|}
\hline $\begin{array}{l}\text { Gene } \\
\text { family }\end{array}$ & $\begin{array}{l}\text { Specific } \\
\text { class }\end{array}$ & $\begin{array}{l}\text { Accession } \\
\text { number }\end{array}$ & 5'primer & 3'primer & $\begin{array}{c}\text { Tm } \\
\left({ }^{\circ} \mathrm{C}\right)\end{array}$ & $\begin{array}{c}\text { PCR fragment } \\
\text { size }(\mathrm{pb})\end{array}$ \\
\hline PR1 & $\begin{array}{l}\text { PR1a, acidic } \\
\text { PR1 }\end{array}$ & X12485.1 & $\begin{array}{l}\text { 5'-TGCTAAGGCTGT- } \\
\text { TGAGATGTGGGTC }\end{array}$ & $\begin{array}{l}\text { 5'-ACTGAACCCTAG- } \\
\text { CACATCCAACACG }\end{array}$ & 58 & 143 \\
\hline PR2 & $\begin{array}{l}\text { PR2a, acidic } \\
\text { glucanase }\end{array}$ & M59443.1 & $\begin{array}{l}\text { 5'-AGCTGTTGGAAA- } \\
\text { TGAAGTCTCTCC }\end{array}$ & $\begin{array}{l}\text { 5'-GCTAAGATCCCT- } \\
\text { GAATATGTTGCAG }\end{array}$ & 59 & 150 \\
\hline EF & $\begin{array}{l}\text { Elongation } \\
\text { Factor-1 } \alpha\end{array}$ & AF120093 & $\begin{array}{l}\text { 5'-CCACAGACAAGC- } \\
\text { CCTCTCAGGCTCC }\end{array}$ & $\begin{array}{l}\text { 5'-TTCAGTGGTCAG- } \\
\text { ACCAGTGGGACC }\end{array}$ & 65 & 149 \\
\hline
\end{tabular}

PR, pathogenesis related protein

Partial characterisation of the GME Total phenolic content was determined colorimetrically using the Folin-Ciocalteu reagent, as described by Emmons and Peterson (2001). Total anthocyanins were quantified using the $\mathrm{pH}$ differential method described by Muñoz-Espada et al. (2004). Soluble sugar content was determined by colorimetric method following the phenol sulphuric acid method as described by Dubois et al. (1956). SA and JA detection were monitored using a Waters Alliance UPLC system containing the separation module E2695 and a Dual $\lambda$ absorbance detector 2487. A $10 \mu \mathrm{L}$ aliquot of GME, SA and JA were injected independently into the column Zorbax SB-CN (Agilent) with the following characteristics $4.6 \mathrm{mmx} 250 \mathrm{~mm} ; 5 \mu \mathrm{m}$. The GME, SA and JA detection wavelength was set at $300 \mathrm{~nm}$. The mobile phase consisted of $40 \%$ acetonitrile and $60 \%$ water acidified at $\mathrm{pH} 1.0$ using $3 \%$ formic acid. The flow rate was set at $1 \mathrm{ml} \mathrm{min}^{-1}$.

Statistical analysis Student's test was used to compare the means of cell death for determination of significant differences between treated samples versus control. The data were written as the mean $\pm \mathrm{SE}$. Values were determined to be significant when $\mathrm{p} \leq 0.05$.

\section{Results}

GME mediates local tissue injury Foliar infiltration of GME into tobacco plants resulted in the appearance of localised HR-like lesions (brown zones). Figure 1 shows the abaxial face of tobacco leaves infiltrated with GME. Infiltration with $0.25 \%$ GME induced a chlorotic area by 2 days post-infiltration (dpi) (Fig.1b). A brown desiccated area appeared within the infiltrated tissue zone at 4 dpi (Fig.1c) and covered most of the infiltrated 
zone by 8 dpi (Fig.1d). Examination of the leaf tissue by UV light $\left(\lambda_{312 \mathrm{~nm}}\right)$ at 8 dpi revealed that the infiltrated area (ia), the surrounding zone (sz) and the necrotic zone (nz) displayed fluorescence indicative of phenolic compound accumulation while the rest of the leaf remained unaffected (Fig.1f). The extent of macroscopic symptoms and the expansion of fluorescent leaf area were induced in a dose-dependent manner. As the concentration of GME decreased (from $0.25 \%$ /dilution 4-fold to $0.0156 \%$ /dilution 64-fold) a reduction of chlorosis within the infiltrated area was observed (Fig.1e). When GME was infiltrated at low concentrations (0.0312\%/dilution 32-fold or $0.0156 \% /$ dilution 64-fold), no macroscopic changes were detected in the infiltrated leaf tissues (Fig.1e). The $0.0625 \%$ (dilution 16-fold) GME concentration induced a very faint chlorotic zone (Fig.1e) with a scattered pattern of fluorescence (Fig.1f). Higher GME concentrations (0.25\%/dilution 4-fold or $0.125 \% /$ dilution 8 -fold) produced the highest chlorotic changes and fluorescence in tobacco leaf tissues with an apparent large necrotic zone (nz) when the highest concentration was used (Fig.1e). As expected, 2 mM SAinfiltrated tissues displayed both necrotic tissue and fluorescent areas (Figs. 1e,f). The $10 \mathrm{mM}$ BABA-infiltrated tissues remained symptomless, similar to the water-infiltrated control tissues.
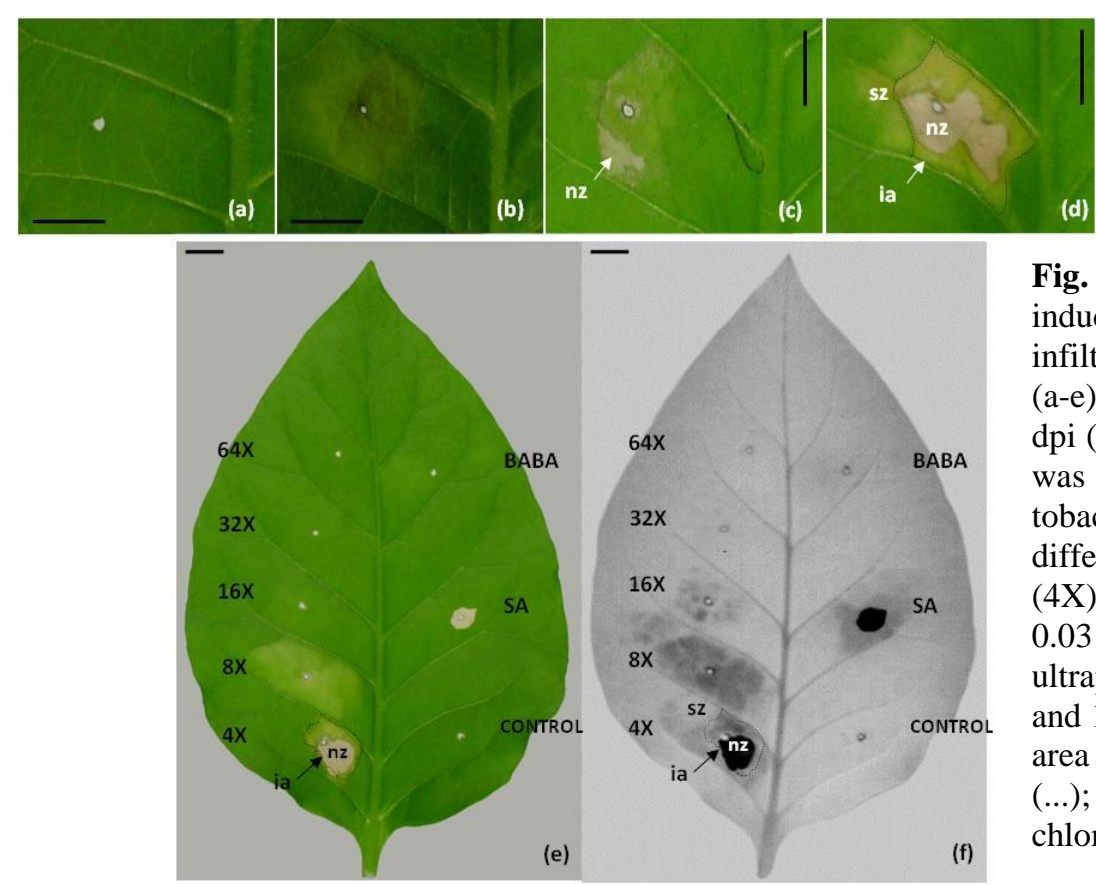

Fig. 1: Macroscopic symptoms induced in tobacco leaves by GME infiltration observed under bright field (a-e) and UV light (f) at 0 dpi (a), 2 dpi (b), 4 dpi (c) and 8 dpi (d-f). GME was infiltrated at $0.25 \%$ (a-d). (e,f): tobacco leaves were infiltrated with different GME concentrations: $0.25 \%$ (4X), $0.125 \%$ (8X), $0.0625 \%$ (16X), $0.0312 \% \quad(32 \mathrm{X}), \quad 0.0156 \% \quad(64 \mathrm{X})$, ultrapure water (control), $2 \mathrm{mM}$ SA and $10 \mathrm{mM} \mathrm{BABA}$. (d-f) the infiltrated area (ia) is delimited by the black line (...); nz, necrotic zone; sz, surrounding chlorotic zone. Bars, $1 \mathrm{~cm}$.

To determine the effect of leaf age on GME response, the macroscopic changes induced by GME infiltration were examined in young and old leaves. Figure 2 shows the HR-like lesions induced by $0.25 \%$ GME at 4 dpi on tobacco plants with 20 to 22 expanded leaves. Younger leaves turned slightly bright (Fig.2a) while older leaves 
displayed shiny chlorotic areas (Fig.2c). Intermediate symptoms were observed on middle leaves (Fig.2b). The increasing severity of induced necrotic lesions with increasing leaf age suggests a greater sensitivity of mature leaves to GME.

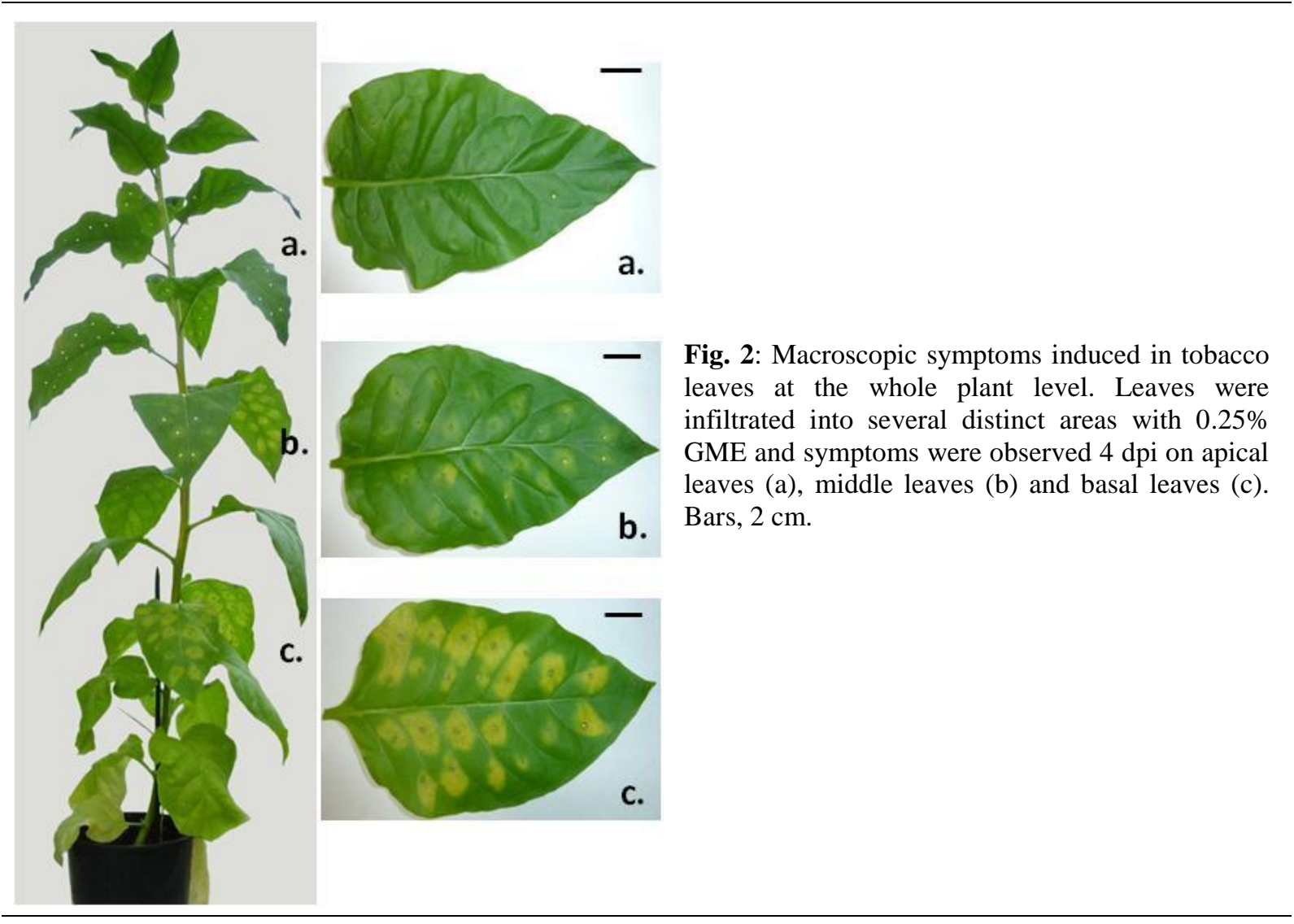

Evans Blue is a stain used to determine cell viability as the non permeating pigment can only enter cells with damaged plasmalemma. The ability of GME to induce tissue injury was evaluated by measuring Evans Blue uptake in infiltrated foliar tissues (Fig.3). Dye accumulation was measured over time from GME infiltrated mature tobacco plant leaves. As observed macroscopically in Figure 1, cell death evidenced by Evans Blue uptake was induced when GME was infiltrated at $0.25 \%$ (dilution 4-fold) or $0.125 \%$ (dilution 8-fold). At the highest GME concentrations applied, lower Evans Blue uptake was measured, which could be attributed to the large necrotic tissues creating a barrier for dye uptake. The $0.0625 \%$ (dilution 16-fold) GME treatment was slightly cell death-inducible. The amount of damaged cells increased relative to the GME treatment with the most significant cell death rate at 8 dpi. These data confirm the ability of GME to induce HR-like lesions including localised cell death. 


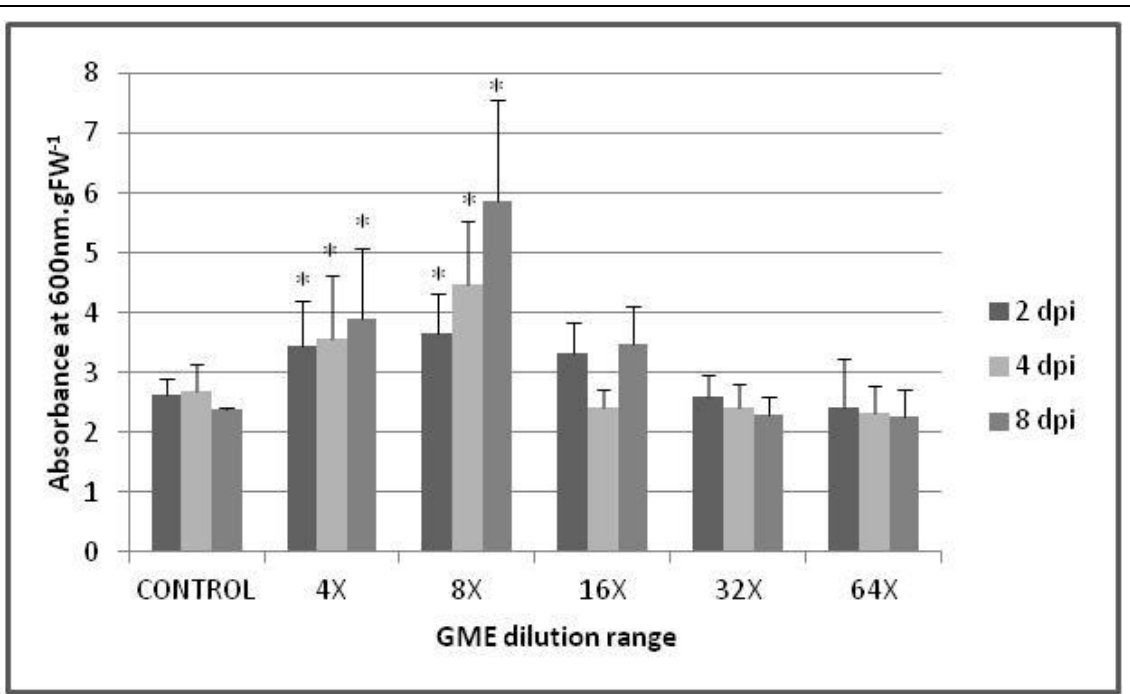

Fig. 3: Cell death assayed by Evans Blue staining in tobacco leaves infiltrated with different concentrations of GME: $0.25 \%$ (4X), $0.125 \%$ (8X), $0.0625 \%$ $(16 X), \quad 0.0312 \% \quad(32 X)$, $0.0156 \%(64 X)$. Leaf extracts were prepared from infiltrated tissues at 2 dpi, 4 dpi and 8 dpi. The control was infiltrated with ultrapure water. Each independent experiment was performed twice and in triplicate for the same leaf. Bars represent the mean values $\pm \mathrm{SE}, * P<0.05$.

GME induces local and systemic PR expression Macroscopic evaluation showed that infiltration with GME induced necrotic lesions. We set out to investigate the GME capability to induce defence-related gene expression in tobacco plants. Transcript levels of defence-related genes coding for PR proteins following GME treatment were assessed by quantitative real-time PCR. The primer pairs designed for the tobacco $P R 1$ and $P R 2$ genes amplified a single isoform as documented by the iCycler melting curve and RT-PCR products electrophoresis analysis which resulted in a single product (data not shown). Total RNA was extracted from different regions of tobacco leaves treated with SA (positive control) or with GME (at 4 dpi, as described in Figure 4a). Leaf tissue was collected from infiltrated zones (IFZ), uninfiltrated zones (UFZ), uninfiltrated leaves (UFL), sprayed leaves (SL) and unsprayed leaves (USL).

As expected, SA treatment dramatically induced $P R I$ and $P R 2$ gene overexpression in IFZ and UFZ. Only the uninfiltrated leaves were weakly responsive to the SA treatment. The foliar spray treatment also induced high levels of $P R 1$ and $P R 2$ gene expression in SL and USL.

High $P R I$ transcript accumulation was induced when GME $(0.25 \%)$ was infiltrated or sprayed on tobacco plants. All treated leaves (IFZ, UFZ, SL) and untreated leaves (UFL and USL) showed hundred times higher level of $P R 1$ transcript accumulation compared with the negative control (Fig 4b). GME also induced $P R 2$ transcript accumulation in tobacco leaves (Fig 4c). Transcriptional activation of $P R 2$ was demonstrated for every tested region of the treated and untreated tobacco leaves. Unlike SA treated-tobacco plants, GME induced higher $P R 2$ 
transcript accumulation in untreated leaves (near 35\%) relative to treated leaves regardless of experimental treatment (i.e., infiltration or spraying).

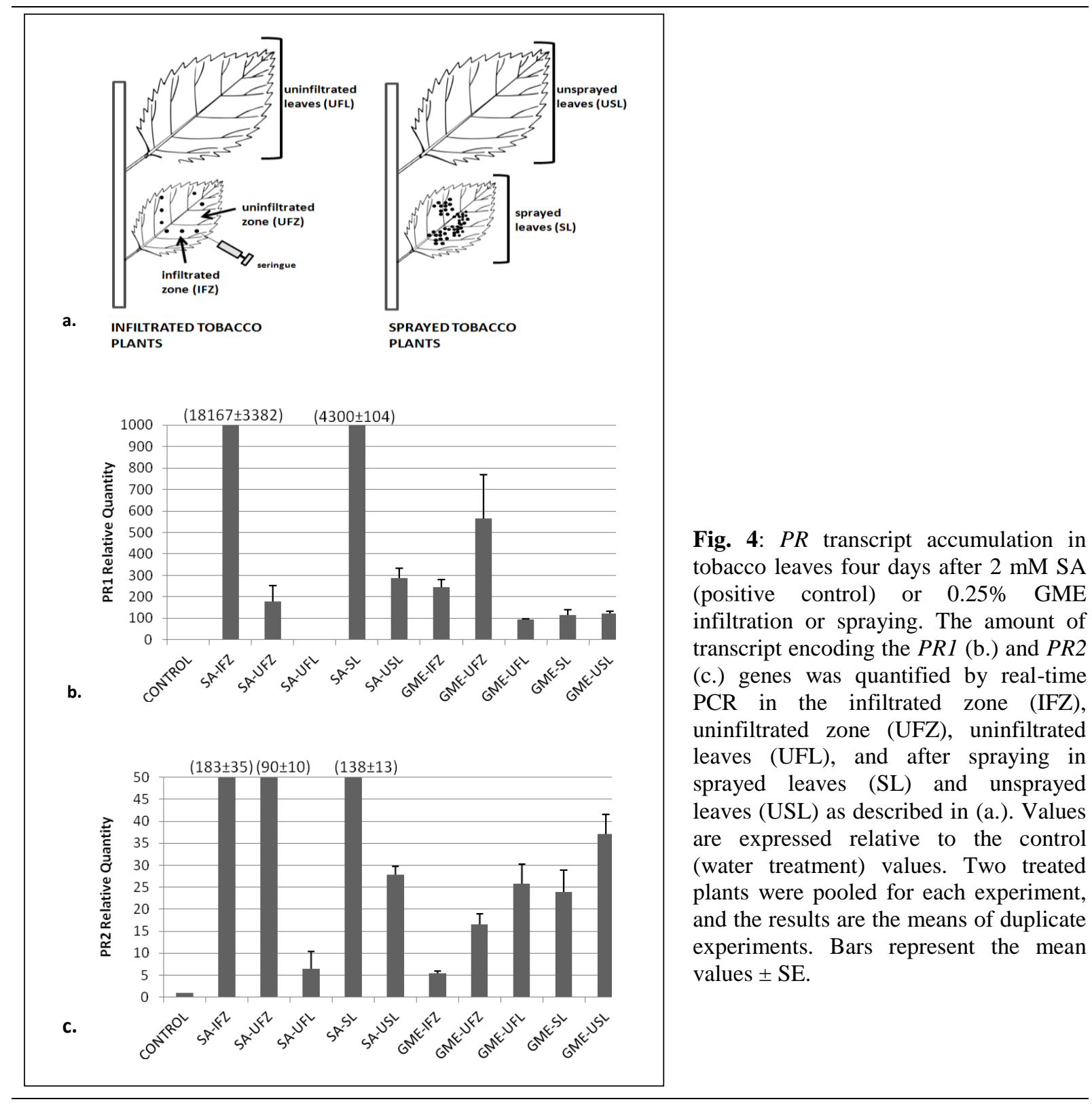

GME-efficiency threshold The accumulation profile of $P R 1$ and $P R 2$ transcripts were analyzed locally and systemically in tobacco plants sprayed with concentrations of GME ranging from $0.25 \%$ to $0.0625 \%$ (Fig.5). The GME doses ranging from $0.25 \%$ (dilution 4-fold) to $0.0625 \%$ (dilution 16-fold) achieved a high level of $P R 1$ and $P R 2$ transcript accumulation both in sprayed and unsprayed tobacco leaves. While the macroscopic effects of GME treatment were barely observed on tobacco leaves at $0.0625 \%$, the induction of both $P R$ target genes was 
noticeable and reached local and systemic 100 times for $P R 1$ and 10 times for $P R 2$ compared with relative transcript levels of the control. At lower GME concentration (dilution 32-fold), PRI and PR2 transcript accumulation reduced dramatically with $P R 1$ transcript upregulation near 15 to 20 -fold and $P R 2$ transcript upregulation near 2 to 6-fold. Treatment of tobacco plants at the lowest GME concentration (dilution 64-fold) did not induce transcriptional activation of $P R 1$ or $P R 2$ meaning that the threshold of GME efficiency to induce $P R$ transcript accumulation was reached following these experimental conditions.

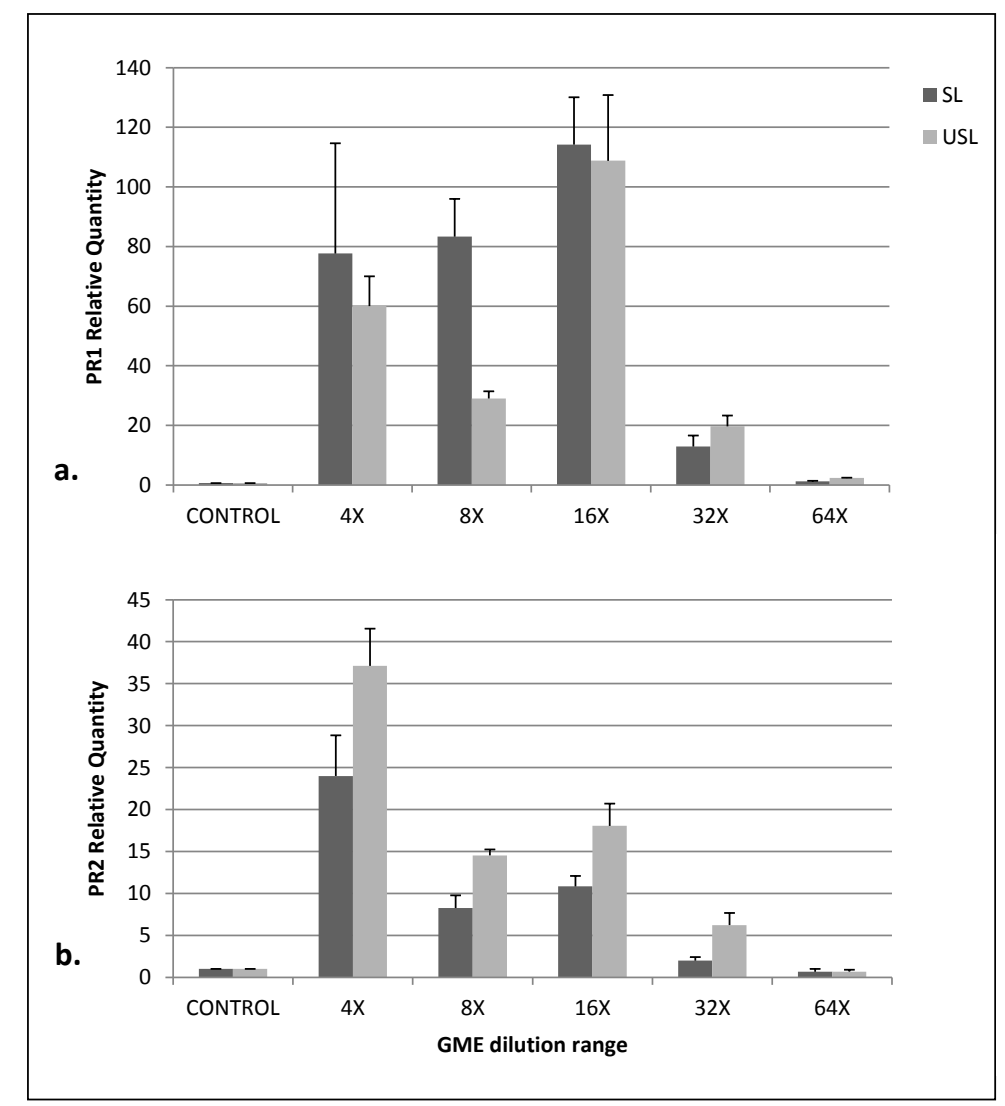

Fig. 5: $P R$ transcript accumulation in tobacco leaves 4 days after GME spraying at different concentrations. The amount of transcript encoding PRI (a.) and PR2 (b.) genes was quantified by real-time PCR in sprayed leaves (SL) and unsprayed leaves (USL). Values are expressed relative to the control (water treatment) values. Two treated plants were pooled for each experiment, and the results are the means of duplicate experiments. Bars represent the mean values $\pm \mathrm{SE}$.

Partial GME-characterisation GME was partially characterized for sugar, polyphenol and anthocyanin contents (Table 2). GME consists mostly of polyphenols (91.2\%) including 3.5\% anthocyanins. These flavonoidbased molecules are responsible for the red colour of the dry extract and the acidic ( $\mathrm{pH} 4.3)$ nature of the aqueous solution when dissolved in water. GME contains low amounts of soluble sugars (0.9\%). While SA and JA are known natural elicitors, these two compounds were not detected by UPLC in the polyphenolic-rich GME aqueous solution (Figure 6). 
Table 2: Partial characterization of GME

\begin{tabular}{lcccc}
\hline & $\mathrm{pH}^{\mathrm{a}}$ & Polyphenols $^{\mathrm{b}}$ & Anthocyanins $^{\mathrm{c}}$ & Soluble sugars $^{\mathrm{d}}$ \\
\hline Grape extract & 4.3 & 91.2 & 3.5 & 0.9 \\
\hline
\end{tabular}

${ }^{\mathrm{a}} \mathrm{pH}$ of a solution of the grape extract at $100 \mathrm{mg}^{-1}$. ${ }^{\mathrm{b}}$ Total polyphenolic content in acid gallic equivalent. ${ }^{\mathrm{c} A n t h o c y a n i n s}$ content in cyanidine-3-glucoside equivalent. ${ }^{\mathrm{d}}$ Soluble sugars in glucose equivalent. ${ }^{\mathrm{a}, \mathrm{b}, \mathrm{c}, \mathrm{d}}$ Measurements in aqueous solution $(0.1 \% \mathrm{~m} / \mathrm{v}) .{ }^{\text {bcd }}$ Contents in $\%(\mathrm{~m} / \mathrm{v})$.

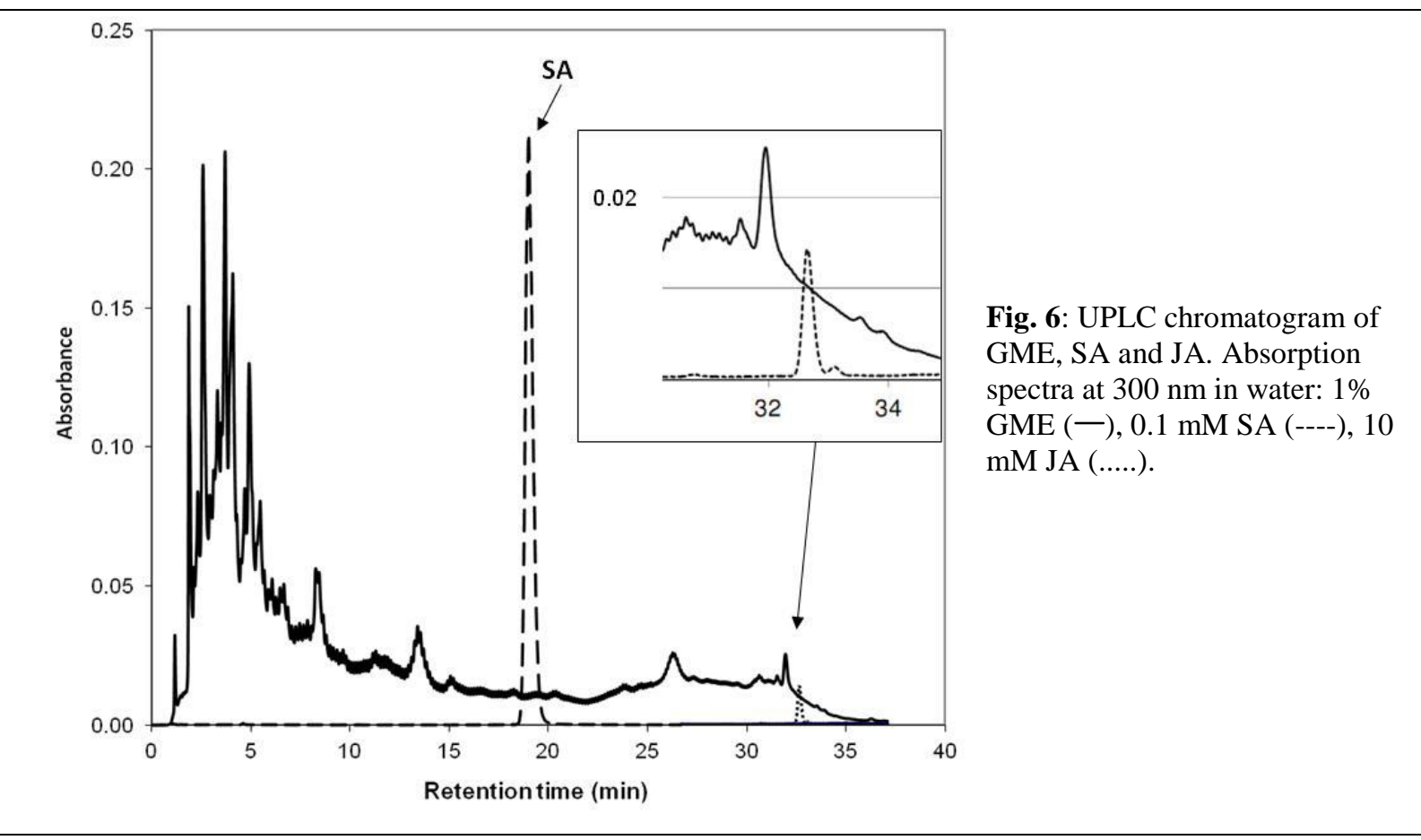

\section{Discussion}

To investigate the PDI activity of the grape marc extract (GME), a range of defence mechanisms including HR,

LAR and SAR were examined in tobacco. SA was used as a positive control and chemical elicitor to induce the expected HR-lesions and pathogenesis related (PR) protein transcript accumulation. The induction of the $P R I$ and $P R 2$ genes was positively coordinated by salicylate treatment with dramatic local and moderate systemic 
amplitudes. $\beta$-aminobutyric acid (BABA) known as a priming compound, was previously used as a positive control capable of developing HR-like lesions when applied at $10 \mathrm{mM}$ on tobacco leaves (Siegrist et al. 2000). In our experiments, no symptoms were observed after BABA infiltration, which might be related to the concomitant action of several defence inducers (GME and SA).

The elicitor activity of GME was evidenced by (i) local injuries and biochemical changes and (ii) a systemic molecular response. GME induced microlesions and cell death when infiltrated into tobacco leaves. After infiltration, the surrounding leaf tissues spread out autofluorescent compounds and produced a local defence reaction with upregulated localised $P R 1$ and $P R 2$ transcript accumulation. These phenomena suggest that GME triggered primary processes resembling those initiated by microbes (Dixon et al. 1994; Hammerschmidt 1999). When applied as a foliar spray, GME induced $P R 1$ and $P R 2$ transcript accumulation on remote leaves. Unlike SA, GME treatment induced both target $P R$ genes with high systemic amplitudes. These data strongly support that GME was perceived by tobacco cells as a PDI and subsequently activated SAR reactions throughout the entire plant. The synthesis of defence-related proteins is a critical step in the establishment of plant disease resistance. Most PR proteins possess antimicrobial activities in vitro and in vivo (Van Loon et al. 2006). The accumulation of both PR1 and PR2 protein transcripts was used to monitor the enhanced defensive state conferred by pathogen-induced SAR (Edreva 2005), and their ectopic overexpression increases resistance to plant pathogens (Evans and Greenland 1998). The ability of GME to induce antimicrobial protein transcripts in planta with high systemic amplitude strongly suggests a potential role as plant protector agent against microbes. Our results showed variable immunity responses at the whole plant level with greater sensitivity to GME and increased production of HR-like microlesions in mature leaves. Young, rapidly growing leaves were less reactive to the GME elicitor molecules than mature leaves. Macroscopic changes associated with hypersensitive cell death were more developed in fully expanded leaves, entering their final developmental stage of senescence. These specific leaf age events illustrated the documented interconnection between plant growth, development and defence (Develey-Rivière and Galiana 2007; Chung et al. 2008). Recent advances in plant immunity research have provided insights into the involvement of plant growth regulators such as $\mathrm{ABA}$, auxins, gibberellins, cytokinins and brassinosteroids. These plant regulators orchestrate both agonistic and antagonistic links between defence and developmental pathways (Bari and Jones 2009; Vlot et al. 2009).

GME elicited a defence response in a dose-dependent manner as measured by $P R$ transcript accumulation. The threshold activity was observed at $312 \mu \mathrm{g} \cdot \mathrm{ml}^{-1}$ (dilution 16 -fold). It is interesting to note that at this GME 
concentration, $P R$ gene expression was upregulated but there was a limited effect on chlorosis and cell death. This indicates that the PR-induced defence response was not proportional to the extent of cell death. Both defensive events were previously described as unrelated phenomena by Mercier et al. (2000). Laminarins commonly used as PDI are potent inducers of defence-related genes but are unable to induce HR-like lesions.

GME is a botanical extract containing a mixture of secondary plant metabolites, primarily polyphenolic compounds ( $\geq 90 \%)$ including anthocyanins. GME does not contain measurable SA or JA concentrations. Most classes of phenolic compounds have shown some involvement in defence, including hydroxybenzoic acids, free and conjugated hydroxycinnamic acids, flavonoids and stilbenes (Grayer and Harborne 1994). GME should contain all these compounds, which have been associated with antimicrobial activity, the ability to form structural barriers, the regulation of cellular redox states and/or antioxidant protection (Hammerschmidt and Hollosy 2008). At this time, only a few biomolecules have been purified and identified as active components from plant extracts. Purified phenolic fractions from Rheum/Frangula extracts are anthraquinone-rich and capable of activating pathogen defense responses in grapevine leaves (Godard et al. 2009). Oligomeric $\beta-1,3-$ glucans (e.g., laminarins) and oligofucans from algae extracts can also act as PDIs (Aziz et al. 2003; Klarzynski et al. 2003). The potential plant defence activity of polyphenolic or oligosaccharidic moiety of the GMEbioactive molecules is under investigation. Preparative HPLC will be used in further studies to fractionate the grape extracts and to individually test each fraction for SAR-inducing reactions. One could assume that grape extract activity would increase upon fractionation and purification. However, the combinatorial action of diverse biomolecules cannot be excluded.

PDIs are emerging as biomolecules with the potential for integration into plant protection strategies (Walling 2001; Vallad and Goodman 2004). In the present paper, we provide molecular evidence of PDI activity with the upregulation of $P R$ genes in tobacco-treated leaves. GME was able to initiate plant defence reactions and therefore, should be classified as a PDIs. The uniqueness of this natural product is a result of its origin and nature since it is a high available by-product generated from food industry processing wastes. It contains natural compounds that are most likely not harmful to crops or to the environment. It has been patented as a new class of photoprotecting agent (Ter Halle et al. 2008) with a previously demonstrated ability to reduce pesticide photodegradation (Eyheraguibel et al. 2010). The dual activity of GME (PDI and pesticide photoprotector) makes this plant product a promising alternative to other chemicals and a challenging issue for sustainable agriculture and green environmental approaches. Future projects will define the threshold defence reactions for 
agronomic crops of interest and identify the pathosystems (crop/pathogens) affected by these protection mechanisms. Molecular characterisation and analysis of the inducible crop resistance spectrum will potentially provide a better knowledge on GME mode of action.

Acknowledgements This work had financial support provided by an ANR Ecophyto 2008-2011 project. We thank Céline Sac for her help in growing tobacco plants and Dominique Marcon for the tobacco leaf images.

\section{References}

Aziz A, Poinssot B, Daire X, Adrian M, Bezier A, Lambert B, Joubert JM, Pugin A (2003) Laminarin elicits defence responses in grapevine and induces protection against Botritis cinerae and Plasmopara viticola. Mol Plant Microbe In 16:1118-1128

Baker CJ, Mock NM (1994) An improved method for monitoring cell death in cell suspension and leaf disc assays using Evans Blue. Plant Cell Tiss Org 39:7-12

Bari R, Jones JDG (2009) Role of plant hormones in plant defence responses. Plant Mol Biol 69:473-488

Baysal Ö, Zeller W (2004) Extract of Hedera helix induces resistance on apple rootstock M26 similar to acibenzolar-S-methyl against fire blight (Erwinia amylovora). Physiol Mol Plant P 65:305-315

Chung K-M, Igari K, Uchida N, Tasaka M (2008) New perspectives on plant defense responses through modulation of developmental pathways. Mol Cells 26:107-112

Conrath U (2006) Systemic acquired resistance. Plant Signal Behav 1:179-184

Costet L, Cordelier S, Dorey S, Baillieul F, Fritig B, Kauffmann S (1999) Relationship between localized acquired resistance (LAR) and the hypersensitive response (HR): HR is necessary for LAR to occur and salicylic acid is not sufficient to trigger LAR. Mol Plant Microbe In 12:655-662

Develey-Rivière M-P, Galiana E (2007) Resistance to pathogens and host developmental stages: a multifaceted relationship within the plant kingdom. New Phytol 175:405-416

Dixon RA, Harrison MJ, Lamb CJ (1994) Early events in the activation of plant defense responses. Annu Rev Phytopathol 32:479-501

Dubois M, Gilles A, Hamilton K, Rebers A, Smith F (1956) Colorimetric method for determination of sugars and related substances. Anal Chem 28:350-356

Durrant WE, Dong X (2004) Systemic acquired resistance. Annu Rev Phytopathol 42:185-209

Edreva A (2004) A novel strategy for plant protection: Induced resistance. J Cell Mol Biol 3:61-69

Edreva A (2005) Pathogenesis-related proteins: research progress in the last 15 years. Gen Appl Plant Physiol $31: 105-124$

Emmons CL, Peterson DM (2001) Antioxydant activity and phenolic content of oat as affected by cultivar and location. Crop Sci 41:1676-1681 
Evans IJ, Greenland AJ (1998) Transgenic approaches to disease protection: applications of antifungal proteins. Pestic Sci 54:353-359

Eyrheraguibel B, Richard C, Ledoigt G, Ter Halle A (2010) Photoprotection by plant extracts: a new ecological means to reduce pesticide photodegradation. J Agr Food Chem 58:9692-9696

Godard S, Slacanin I, Viret O, Gindro K (2009) Induction of defence mechanisms in grapevine leaves by emodin- and anthraquinone- rich extracts and their conferred resistance to downy mildew. Plant Physiol Biochem 47:827-837

Grayer RJ, Harborne JB (1994) A survey of antifungal compounds from higher plants, 1982-1993. Phytochem $37: 19-42$

Hammerschmidt R (1999) Induced resistance: how do induced plants stop pathogens? Physiol Mol Plant P $55: 77-84$

Hammerschmidt R, Hollosy SI (2008) Phenols and the onset and expression of plant disease resistance. In: F. Daayf F. and Lattanzio V. (eds) Recent advances in polyphenol research. vol.1. Blackwell Publishing Ltd, Oxford, pp 211-227

Harm A, Kassemeyer H-H, Seibicke T, Regner F (2011) Evaluation of chemical and natural resistance inducers against downy mildew (Plasmopara viticola) in grapevine. Am J Enol Vitic 62:184-192

Konstantinidou-Doltsinis S, Markellou E, Kasselaki M, Fanouraki MN, Koumaki CM, Schmitt A, LiopaTsakalidis A, Malathrakis NE (2006) Efficacy of Milsana, a formulated plant extract of Reynoutria sachalinensis, against powdery mildew of tomato (Leveillula taurica). Biocontrol 51:375-392

Klarzynski O, Descamps V, Plesse B, Yvin JC, Kloareg B, Fritig B (2003) Sulfated fucan oligosaccharides elicit defense responses in tobacco and local and systemic resistance against tobacco mosaic virus. Mol Plant Microbe In 16:115-122

Lyon G. (2007) Agents that can elicit induced resistance. In: Walters D, Newton A, Lyon G (eds) Induced resistance for plant defence. A sustainable approach to crop protection. Blackwell Publishing Ltd, Oxford, pp 929

Martinez C, Baccou JC, Delpech L, Delrieux M, Cassan H (2006) Elicitor made from Trigonella foenum graecum extracts for the treatment of plant pathogens, use thereof, and method for the production thereof. WO/2004/107864.

Mercier L, Lafitte C, Borderies G, Briand X, Esquerré-Tugayé M-T, Fournier J (2000) The algal polysaccharide carrageenans can act as an elicitor of plant defence. New Phytol 149:43-51

Muñoz-Espada AC, Wood KV, Bordelon B, Watkins BA (2004) Anthocyanin quantification and radical scavenging capacity of Concord, Norton, and Marechal Foch grapes and wines. J Agr Food Chem 52:6779-6786

Peng J-L, Bao Z-L, Ren H-Y,wang J-S, Dong H-S (2004) Expression of harpin ${ }_{\mathrm{Xoo}}$ in transgenic tobacco induces pathogen defense in the absence of hypersensitive cell death. Phytopathol 94:1048-1055

Pfaffl MW (2001) A new mathematical model for relative quantification in real-time RT-PCR. Nucl Acids Res 29:2002-2007

Reglinski T, Dann E, Deverall B (2007) Integration of induced resistance in crop production. In: Walters D, Newton A, Lyon G (eds) Induced resistance for plant defence. A sustainable approach to crop protection. Blackwell Publishing Ltd, Oxford, pp 210-223

Reignault P, Walters D (2007) Topical application of inducers for disease control. In: Walters D, Newton A, Lyon G (eds) Induced resistance for plant defence. A sustainable approach to crop protection. Blackwell Publishing Ltd, Oxford, pp 179-199

Shah J (2009) Plants under attack: systemic signals in defence. Curr Opin Plant Biol 12:459-464 
Siegrist J, Orober M, Buchenauer H (2000) $\beta$-aminobutyric acid-mediated enhancement of resistance in tobacco to tobacco mosaic virus depends on the accumulation of salicylic acid. Physiol Mol Plant P 56:95-106

Ter Halle A, Richard C, Ledoigt G (2008) Phytosanitary formulations containing plant extracts as photoprotectants for pesticides. WO/2008/090476.

Vallad GE, Goodman RM (2004) Systemic acquired resistance and induced systemic resistance in conventional agriculture. Crop Sci 44:1920-1934

Van Loon LC, Rep M, Pieterse CMJ (2006) Significance of inducible defence-related proteins in infected plants. Annu Rev Phytopathol 44:135-162

Vernooij B, Friedrich L, Ahl-Goy P, Staub T, Kessmann H, Ryals J (1995) 2,6-dichloroisonicotinic acid-induced resistance to pathogens does not require the accumulation of salicylic acid. Mol Plant Microbe In 8:228-234

Vlot AC, Dempsey MA, Klessig DF (2009) Salicylic acid, a multifaceted hormone to combat disease. Annu Rev Phytopathol 4:177-206

Walling LL (2001) Induced resistance: from the basic to the applied. Trends Plant Sci 6:445-447

Walters D, Walsh D, Newton A, Lyon G (2005) Induced resistance for plant disease control: maximizing the efficacy of resistance elicitors. Phytopathology 95:1368-1373

Yang Y, Shah J, Klessig DF (2011) Signal perception and transduction in plant defence responses. Genes Dev 11:1621-1639 